\title{
PEMBELAJARAN DALAM JARINGAN (DARING) BERBASIS WHATSAPP DI SD YAPITA
}

\author{
Arindra Evandian Bhagaskara \\ Universitas Islam Negeri Sunan Ampel Surabaya \\ bhagasforstudy@gmail.com
}

\section{Eka Nur Afifah}

Universitas Islam Negeri Sunan Ampel Surabaya

ekanurafifah1@gmail.com

\section{Enggar Maulana Putra}

Universitas Islam Negeri Sunan Ampel Surabaya enggarmaulanaputra@gmail.com

\begin{abstract}
The learning process at the time Covid-19 must be implemented online. The use of media in learning is very important. The whatsapp application was chosen to be used in this online learning. This study aims to obtain information about the application of the WhatsApp application in online learning and to find out what are the advantages and disadvantages of using the WhatsApp application in online learning. The research subjects here are the teachers and students of SD Yapita Surabaya and the object under study is the use of the WhatsApp application in online learning. This study used a qualitative research design. The instruments used in this study were observation, surveys and interviews. The results obtained are that the application WhatsApp can be applied in the learning process online and there are also deficiencies in its application, namely the existence of obstacles regarding face-to-face implementation through the existing features of the WhatsApp application and the absence of features to limit student work time and for the advantages the WhatsApp application is able to accommodate the implementation of the learning process well.
\end{abstract}

Keyword: Learning, Online Learning, Whatsapp, Covid-19

\begin{abstract}
Abstrak
Proses pembelajaran pada masa Covid-19 harus dilaksanakan secara daring. Penggunaan media dalam pembelajaran menjadi sangat penting. Aplikasi whatsapp dipilih untuk digunakan dalam pembelajaran daring ini. Penelitian ini bertujuan mendapatkan informasi mengenai penerapan aplikasi whatsapp dalam pembelajaran daring dan untuk menemukan apa saja kekurangan dan kelebihan dari penggunaan aplikasi whatsapp dalam pembelajaran daring. Subjek penelitian disini adalah Guru dan siswa SD Yapita Surabaya dan objek yang diteliti adalah penggunaan aplikasi whatsapp dalam pembelajaran daring. Penelitian ini menggunakan desain penelitian kualitatif. Instrumen yang digunakan dalam penelitian ini adalah observasi, survei dan juga wawancara. Hasil penelitian yang didapat ialah bahwa aplikasi whatsapp dapat diterapkan dalam proses pembelajaran secara daring dan juga ditemukan kekurangan dalam penerapannya yaitu adanya kendala mengenai pelaksanaan tatap muka melalui fitur yang ada pada aplikasi whatsapp serta kendala dalam tidak adanya fitur untuk membatasi waktu pengerjaan tugas siswa dan untuk kelebihannya aplikasi whatsapp mampu mengakomadasi pelaksanaan proses pembelajaran dengan baik.
\end{abstract}

Kata Kunci: Pembelajaran, Pembelajaran Daring, Whatsapp, Covid-19

Program Studi Pendidikan Guru Madrasah Ibtidaiyah

STAI Al-Azhar Menganti Gresik, Indonesia

\section{Pendahuluan}

Terdapat dua faktor penting dalam keberlangsungan pendidikan di Indonesia, yaitu belajar dan pembelajaran. Belajar merupakan sebuah interaksi yang dilakukan antara guru dan siswa secara sadar, baik di dalam atau di luar ruangan yang memiliki tujuan untuk 
ZAHRA: Research And Tought Elmentary School Of Islam Journal Vol. (2) (1), (Maret)(2021), (Halaman)(13-23)| 14 meningkatkan kemampuan siswa (Afandi, Chamalah, \& Wardani, 2013). Sedangkan Pembelajaran sendiri jika dilihat dari teori interaksional memiliki makna bahwa proses pembelajaran merupakan sebuah interaksi antara siswa, guru dan juga sumber belajar yang dilaksanakan dalam sebuah lingkungan belajar (Nurdyansyah \& Fahyuni, 2016). Dampak wabah COVID-19 ini sangat dirasakan oleh lapisan penduduk dunia termasuk masyarakat indonesia. Awalnya dampak ini hanya dirasakan pada aspek ekonomi yang semakin melemah, ternyata dampak wabah COVID-19 ini juga dirasakan oleh semua lapisan aspek kehidupan. Termasuk aspek pendidikan, dalam menghadapi situasi ini kementerian Pendidikan dan Kebudayaan Republik Indonesia menerbitkan surat edaran nomor 4 tahun 2020 yang mengatur pelaksanaan pendidikan dalam darurat penyebaran COVID-19. Pembelajaran daring menjadi tantangan baru bagi pendidik. dampak yang dirasakan oleh pendidik saat ini adalah kesulitan dalam proses pembelajaran. Hal ini juga berlaku bagi siswa yang ada di pendidikan dasar seperti SD atau MI. Menurut (Aji, Dewi, Kristen, \& Wacana, 2020) dalam penelitiannya menyatakan bahwa pembelajaran bagi siswa SD harus dilaksanakan sacara daring atau tanpa adanya tatap muka secara langsung. Pembelajaran yang seharusnya dilaksanakan dengan tatap muka harus diganti menjadi pembelajaran daring. Adanya peraturan tentang keharusan untuk tidak melaksanakan pembelajaran tatap muka akhirnya memunculkan beberapa opsi-opsi media pembelajaran yang dapat digunakan dalam pembelajaran daring. Pemanfaatan teknologi dalam kondisi pandemi COVID-19 ini sangat penting dilakukan. (Hamalik, 2013) menyampaikan bahwa teknologi merupakan penyampaian pesan yang dapat digunakan untuk membantu pelaksanaan sebuah proses pembelajaran. Dalam jurnal (Abidah, Hidaayatullaah, Simamora, Fehabutar, \& Mutakinati, 2020) menyatakan bahwa ada beberapa media pembelajaran yang dapat diakses guru, siswa dan orang tua secara gratis antara lain ialah google Indonesia, Ruangguru, Sekolahmu, Zenius, Quipper, smart class dan microsoft. Selain itu pembelajaran daring dapat dilakukan dengan pemanfaatan beberapa media sosial seperti twitter, youtube, instagram, facebook dan juga bisa menggunakan aplikasi berbasis chat seperti google classroom, whatsapp dan zoom. Pemilihan metode yang tepat untuk ketercapaian tujuan pembelajaran sekaligus juga bisa menjaga kesehatan siswa dari penularan virus COVID-19 sekarang telah menjadi tugas tambahan bagi guru dan juga sekolah. Hal ini senada dengan penelitian (Hakim \& Mulyapradana, 2020) bahwa adanya permasalahan seperti ini yang menuntut pembelajaran dilakukan secara daring atau tidak melakukan tatap muka dengan siswa, dapat mendorong seorang guru untuk lebih berfikir kreatif dalam menyikapi keadaan yang terjadi serta lebih 
ZAHRA: Research And Tought Elmentary School Of Islam Journal Vol. (2) (1), (Maret)(2021), (Halaman)(13-23)| 15 pandai dalam menggunakan serta memanfaatkan teknologi untuk menunjang keberhasilah pembelajaran secara daring.

Pembelajaran secara tatap muka di SD Yapita Surabaya resmi diganti dengan pembelajaran dalam jaringan atau daring yaitu sekitar akhir bulan Maret 2020. Sesuai dengan surat edaran kementerian dan kebudayaan, yang menyatakan bahwa proses pembelajaran secara tatap muka tidak boleh dilaksanakan demi menjaga kesehatan dan menghentikan penularan virus COVID-19. Pembelajaran daring sendiri merupakan pembelajaran yang dilakukan dalam jaringan atau dengan kata lain melalui internet serta alat penunjang lainnya seperti smartphone atau televisi (Putria, Maulana, \& Uswatun, 2020). Pembelajaran daring sendiri merupakan model pembelajaran yang tidak memerlukan adanya tatap muka secara langsung, akan tetapi proses pembelajarannya sendiri masih tetap bisa berjalan. Karena pembelajaran daring memiliki keterbatasan ruang dan waktu, artinya adalah proses pembelajaran bisa dilaksanakan dimana saja dan kapan saja (Sofyana \& Rozaq, 2019). Penggunaan media mobile seperti smartphone memiliki andil yang sangat besar dalam proses pembelajaran daring karena pelaksanaan pembelajaran daring (Sadikin \& Hamidah, 2020). Hal tersebut juga senada dengan penelitian (Khusniyah \& Hakim, 2019), bahwa teknologi komunikasi merupakan sarana yang sangat penting digunakan dalam pelaksanaan proses pembelajaran jarak jauh.

Melaksanakan pembelajaran secara daring diperlukan adanya media pendukung selain alat penunjang seperti internet, smartphone, atau juga komputer. Dan salah satu aplikasi yang bisa digunakan ialah aplikasi whatsapp. Seperti yang disampaikan dalam penelitian (Amal, 2019) bahwa aplikasi whatsapp merupakan sebuah media yang dapat menghubungkan banyak orang dalam satu waktu. Hal ini cocok dengan penerapannya dalam sebuah proses pembelajaran, karena dalam suatu proses pembelajaran pastinya guru akan melakukan komunikasi dengan banyak siswa. Selain itu ada beberapa faktor lain kenapa aplikasi whatsapp ini cocok digunakan dalam proses pembelajaran daring. Diantaranya ialah karena di dalam aplikasi whatsapp juga terdapat beberapa fasilitas atau fitur yang bisa digunakan dalam menunjang pembelajaran daring. Hal ini sesuai dengan yang dipaparkan dalam penelitian (Sahidillah \& Miftahurrisqi, 2019) bahwa aplikasi whatsapp memiliki beberapa fitur diantaranya adalah fitur berkirim pesan, berbagi gambar atau video, berbagi dokumen hingga melakukan video call dengan siswa. Selain memiliki beberapa fitur yang bisa diterapkan delam proses pembelajaran secara daring. Aplikasi whatsapp juga merupakan aplikasi yang sudah tidak asing digunakan baik itu oleh orangtua atau juga siswa itu sendiri. Hal ini sejalan dengan yang disampaikan dalam penelitian (Nurhayati \& Lestari, 2020) 
ZAHRA: Research And Tought Elmentary School Of Islam Journal Vol. (2) (1), (Maret)(2021), (Halaman)(13-23)| 16 bahwa guru, siswa dan orangtua siswa sebelum adanya perintah untuk melakukan pembelajaran secara daring sudah menggunakan aplikasi whatsapp untuk berkomunikasi. Baik itu untuk menyampaikan informasi atau kegiatan sekolah atau untuk menanyakan perkembangan dan kegiatan siswa di sekolah. Hal ini menunjukkan bahwa aplikasi whatsapp merupakan aplikasi yang mampu menunjang proses pembelajaran secara daring baik dari segi fitur yang dimiliki dan juga banyaknya guru, siswa dan orang tua siswa yang menggunakan aplikai whatsapp ini.

Penelitian terdahulu yang pernah meneliti tentang pembelajaran daring dan juga penggunaan aplikasi whatsapp diantaranya ialah Pertama, Penelitian (Utomo \& Ubaidillah, 2018) yang meneliti tentang pemanfaatan aplikasi whatsapp dalam model pembelajaran berbasis masalah terhadap hasil belajar. Kesimpulan akhir dari penelitian tersebut ialah penggunaan aplikasi whatsapp dalam model pembelajaran berbasis masalah dapat meningkatkan hasil belajar. kedua, penelitian (Pratama \& Yusro, 2016) yang mengkaji mengenai pengimplementasian aplikasi whatsapp untuk meningkatkan hasil belajar mahasiswa. Dalam penelitian tersebut didapatkan kesimpulan bahwasannya penggunaan aplikasi whatsapp dapat meningkatkan hasil belajar mahasiswa. Ketiga, penelitian (Prajana et al., 2018) yang membahas mengenai pemanfaatan aplikasi whatsapp sebagai media pembelajaran e-learning. Dan kesimpulan yang didapat dari penelitian tersebut ialah aplikai whatsapp dapat diterapkan sebagai media e-learning. Dari beberapa penelitian tersebut mengkaji dan membahas mengenai penggunaan aplikasi whatsapp dalam pembelajaran daring khususnya pada mahasiswa, sedangkan penelitian berikut ini akan membahas mengenai pembelajaran daring berbasis whatsapp yang diterapkan untuk siswa sekolah dasar. Tujuannya ialah untuk menganalisis pelaksanaan pembelajaran daring yang dilakukan dengan menggunakan aplikasi whatsapp di SD Yapita Surabaya. Permasalahan utama yang akan dibahas dan dikaji dalam penelitian ini ialah bagaimana proses pelaksanaan pembelajaran daring berbasis whatsapp di SD Yapita Surabaya dan juga apa saja kekurangan dan kelebihan dari pembelajaran berbasi whatsapp ini. Melalui hasil penelitian yang akan didapatkan dari penelitian ini diharapkan bisa menjadi inovasi baru dalam pembelajaran daring terutama bagi siswa di sekolah dasar serta kedepannya akan ada perbaikan dari kekurangan selama proses pembelajaran secara daring berbasis whatsapp ini.

\section{Metode Penelitian}

Desain yang digunakan dalam penelitian tentang analisis pembelajaran daring berbasis whatsapp ini adalah desain penelitian kualitatif. Hal ini bertujuan untuk mendapatkan hasil penelitian yang natural dan tanpa adanya rekayasa dalam proses 
ZAHRA: Research And Tought Elmentary School Of Islam Journal Vol. (2) (1), (Maret)(2021), (Halaman)(13-23)| 17 penelitiannya. Hal ini senada dengan yang disampaikan (Sugiyono, 2013) bahwa desain penelitian kualitatif ini merupakan desain penelitian yang memiliki kondisi yang natural dalam proses penelitiannya dan juga tanpa adanya rekayasa. Desain ini merupakan desain penelitian yang digunakan untuk meneliti suatu kondisi yang alamiah, dimana peneliti adalah sebagai instrumen utama dalam penelitian. Tahapan penelitian yang dilaksanakan ialah diawali dengan studi pendahuluan, menentukan masalah, menentukan model penelitian yang digunakan, menyusun instrumen penelitian, mengumpulkan data, mentabulasi data, menyajikan data, mendeskripsikan data, mengintrepetasi data serta menarik kesimpulan. Pengumpulan data dalam penelitian ini akan diambil melalui tiga teknik, Pertama, observasi untuk mengamati proses pelaksanaan pembelajaran dengan aplikasi whatsapp. Kedua, wawancara yang dilakukan pada kepala sekolah, guru, siswa dan orangtua siswa untuk mengidentifikasi kelebihan dan kekurangan penerapan aplikasi whatsapp dalam pembelajaran dan ketiga dokumentasi untuk mendapatkan data berupa foto yang berkaitan dengan pelaksanaan pembelajaran daring berbasis whatsapp. Instruman yang akan digunakan adalah lembar pedoman observasi lapangan, lembar pedoman wawancara dan cek list dokumentasi. Narasumber yang akan digunakan sebagai informan adalah kepala sekolah, guru, siswa dan orangtua siswa. Data dalam penelitian ini akan ditampilkan dalam bentuk gambar, tabel dan juga dijelaskan secara deskriptif. Subjek yang ada dalam penelitian ini adalah guru dan siswa SD Yapita Surabaya, dan objek yang diteliti adalah pembelajaran daring berbasis whatsapp.

\section{Hasil Penelitian}

Lokasi penelitian ini dilaksanakan di SD Yapita Surabaya. Waktu pelaksanaan penelitian ini ialah pada bulan November tahun 2020. Adapun hasil penelitian ini didapatkan melalui wawancara dengan kepala sekolah SD Yapita Surabaya, Guru, Orang tua siswa dan juga siswa sendiri. Selain itu hasil penelitian ini juga didapatkan dari observasi langsung pada proses pembelajaran melalui Group Whatsapp guru dan siswa.

Pembelajaran dalam jaringan (daring) yang berlangsung di SD Yapita sudah berlangsung mulai akhir bulan Maret tahun ini. Proses pembelajaran ini berlangsung di latar belakangi adanya pandemi wabah penyakit Covid-19 yang mulai masuk ke Indonesia pada awal tahun 2020. Proses pembelajaran yang biasanya dilaksanakan secara langsung dengan bertatap muka antara siswa dan guru akhirnya harus diganti dengan pembelajaran secara daring. Hal ini dilakukan dengan tujuan untuk memutus rantai penyebaran virus Covid-19, karena institusi pendidikan menjadi salah satu tempat yang bisa memudahkan virus Covid-19 untuk menyebar ke setiap individu karena interaksi antar individu di dalam sekolah begitu tinggi. Baik dari guru dengan siswa, guru dengan guru dan juga siswa dengan sesama siswa yang lain. 
ZAHRA: Research And Tought Elmentary School Of Islam Journal Vol. (2) (1), (Maret)(2021), (Halaman)(13-23)| 18

Terjadinya perubahan yang mendadak ini akhirnya memaksa guru untuk merubah proses pembelajaran yang awalnya dilaksanakan secara langsung menjadi proses pembelajaran secara daring (dalam jaringan). Yang akhirnya menuntut guru menggunakan internet sebagai sarana menyampaikan materi dalam proses pembelajaran. Seperti halnya yang disampaikan dalam penelitian (Handarini \& Wulandari, 2020) bahwa dalam proses pembelajaran daring ini memerlukan ketersediaan sarana dan prasarana yang memadai seperti komputer atau laptop, smartphone dan jaringan internet. Selain itu hal senada juga disampaikan dalam penelitian (Putria et al., 2020) bahwa dalam melaksanakan pembelajaran daring juga memerlukan adanya pulsa kuota internet serta jaringan internet yang stabil. Sehingga sebelum memutuskan untuk menentukan aplikasi apa yang akan digunakan, pihak guru terlebih dahulu melakukan diskusi dengan kepala sekolah, guru yang lain dan juga orang tua siswa. Dengan tujuan agar nantinya bisa mendapatkan aplikasi yang paling sesuai dan paling mudah digunakan. Hal ini senada dengan penelitihan (Rigianti, 2020) bahwa dalam menentukan aplikasi apa yang digunakan perlu adanya diskusi terlebih dahulu dengan pihak-pihak terkait. agar didapatkan aplikasi yang paling mudah untuk digunakan oleh siswa dan juga guru. Dan hasil kesepakatan yang didapatkan ialah bahwa aplikasi yang digunakan dalam proses pembelajaran dalam jaringan ini ialah aplikasi whatsapp. Aplikasi ini dipilih berdasarkan beberapa pertimbangan yaitu dikarenakan aplikasi whatsapp sebelumnya memang telah digunakan oleh guru sebagai media penyampaian informasi yang ada di sekolah kepada orangtua siswa, sehingga guru, orangtua siswa serta siswa sendiri juga bisa lebih mudah dalam menggunakan aplikasi tersebut, dikarenakan telah terbiasa menggunakan aplikasi ini sebelumnya.

Proses pembelajaran dalam jaringan berbasis whatsapp ini difokuskan pada pemanfaatan beberapa jenis fitur yang bisa digunakan. Dalam proses pembelajaran daring menggunakan aplikasi whatsapp ini digunakan beberapa fasilitas yaitu :

Tabel 1. Fitur Aplikasi Whatsapp dan Kegunaannya

\begin{tabular}{ll}
\hline \multicolumn{1}{c}{ Fasilitas aplikasi whatsapp } & \multicolumn{1}{c}{ Kegunaan } \\
\hline Grup chat & Sebagai forum berkumpulnya antara guru dan siswa \\
\hline Kamera / Galeri & Membagikan gambar / video \\
\hline Share dokumen & Membagikan file berbentuk dokumen \\
\hline Voice note & Membagikan pesan suara \\
\hline Audio & Membagikan suara atau musik \\
\hline Youtube video box & Membagikan video langsung dari youtube \\
\hline
\end{tabular}

Fitur ini merupakan bagian dari aplikasi whatsapp yang paling sering digunakan dalam proses pembelajaran. Pertama yang paling penting ialah fitur Grup chat, fitur ini digunakan sebagai forum berkumpulnya antara guru dan juga siswa (Prajana et al., 2018). Grup ini menjadi tempat untuk berdiskusi, bertanya jawab dan juga untuk membagikan materi pelajaran setiap harinya. Grup ini berisikan nomor handphone orang tua siswa dan juga guru yang sudah terhubung dengan aplikasi whatsapp. Meskipun nomor yang dimasukkan ialah nomor dari orang tua siswa, akan tetapi ketika proses pembelajaran berlangsung yang menggunakan aplikasi ini merupakan para siswa. Hal ini dapat 
ZAHRA: Research And Tought Elmentary School Of Islam Journal Vol. (2) (1), (Maret)(2021), (Halaman)(13-23)| 19 dilihat dari absensi kehadiran yang dibuktikan dengan mengirim foto siswa yang bersangkutan ketika sedang belajar di grup whatsapp kelas. Fitur kedua ialah kamera/gambar. Fitur ini digunakan oleh guru sebagai cara untuk menyampaikan materi pembelajaran yang berbentuk gambar atau pun video kepada siswa. Dan bagi siswa, fitur ini digunakan untuk mengirimkan foto atau video bukti kehadiran atau hasil dari tugas yang diberikan guru di grup whatsapp kelas (Sahidillah \& Miftahurrisqi, 2019). Ketiga ialah share dokumen, fitur ini digunakan oleh guru untuk membagikan file berupa dokumen berisi materi pelajaran seperti dalam bentuk word atau powerpoint. Keempat ialah fitur voice note. Dikarenakan mengirim materi atau tugas dalam bentuk foto atau video akan lebih menguras kuota internet (Rigianti, 2020). Maka fitur ini digunakan sebagai alternatif dalam menyampaikan tugas oleh guru dan mengerjakan tugas oleh siswa. Fitur kelima ialah audio, fitur ini digunakan untuk mengirim file dalam bentuk suara atau lagu yang telah disimpan sebelumnya kepada siswa. Seperti halnya lagu atau instrumen musik. Dan fitur keenam ialah youtube video box, fitur ini berfungsi sebagai sarana membagikan video secara langsung melalui media youtube kepada siswa, sehingga tanpa harus membuka aplikasi youtube, siswa sudah bisa melihat video tersebut melalui aplikasi whastapp (Prajana et al., 2018).

Dalam pelaksanaannya proses pembelajaran daring ini diawali dengan memasukkan dulu nomor whatsapp orangtua siswa ke dalam grup chat yang ada di aplikasi whatsapp. Setelah semua nomor orangtua siswa sudah masuk ke dalam grup chat kelas maka pembelajaran secara daring sudah siap untuk dimulai. Pembelajaran diawali dengan guru mengucapkan salam kepada siswa, menanyakan kabar siswa dan membuka pembelajaran dengan berdo`a. Kegiatan ini bisa dilakukan dengan menggunakan fitur kamera, pesan suara atau teks yang ada di aplikasi whatsapp. Seperti yang ada pada gambar 1 .

Gambar 1. Proses Pembelajaran Melalui Aplikasi Whatsapp

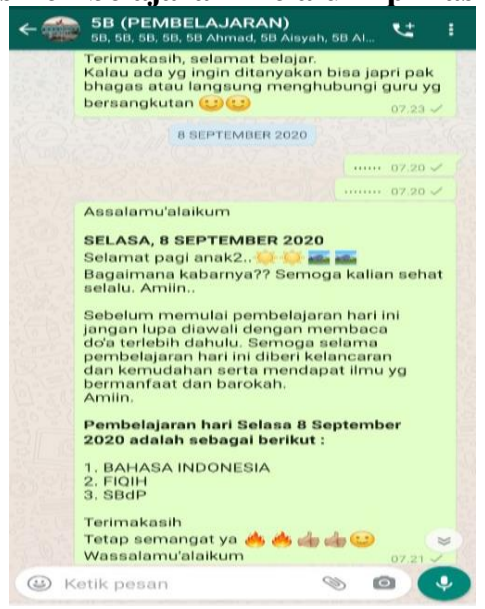

Gambar 2. Contoh foto absensi kehadiran siswa dalam pembelajaran dalam jaringan 


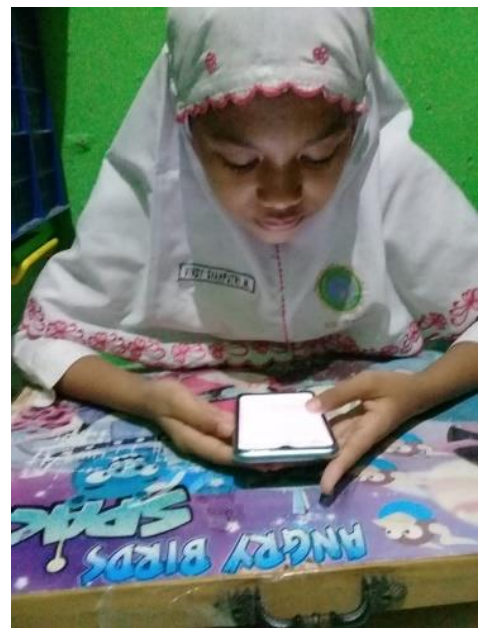

Gambar 3. Proses Penyampaian Materi Pembelajaran

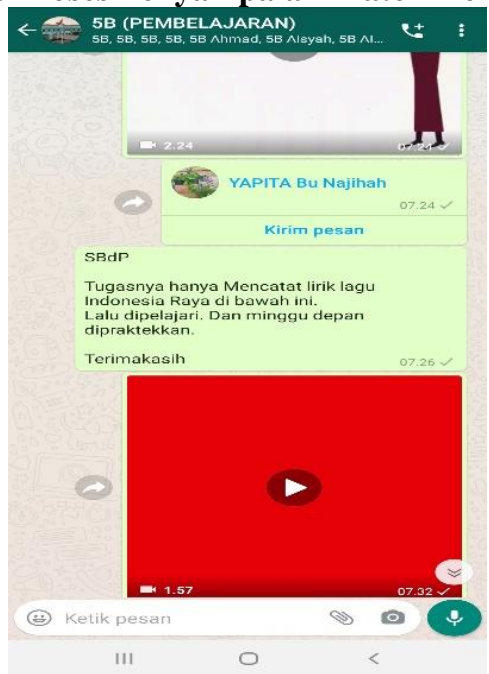

Gambar 4. Proses Pengumpulan Tugas Melalui Chat Pribadi dengan Guru

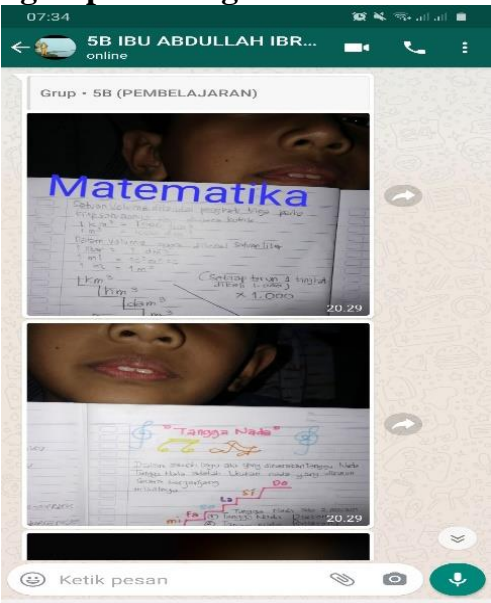

Kegiatan selanjutnya adalah siswa melakukan absensi kehadiran dengan mengirimkan foto ketika mereka sedang melaksanakan proses pembelajaran seperti yang ada pada gambar 2. Setelah melakukan absensi kehadiran kegiatan selanjutnya ialah guru memberikan materi pembelajaran kepada siswa melalui beberapa cara, bisa melalui pesan suara, video pembelajaran atau mengirimkan materi dalam bentuk dokumen seperti power point materi, seperti yang ada di gambar 3. Setelah itu siswa diberikan kesempatan untuk mempelajari materi yang diberikan dan guru membuka sesi tanya 
ZAHRA: Research And Tought Elmentary School Of Islam Journal Vol. (2) (1), (Maret)(2021), (Halaman)(13-23)| 21 jawab bagi siswa yang masih kurang faham. Setelah dirasa cukup untuk sesi tanya jawab, maka kegiatan selanjutnya ialah guru memberikan tugas kepada siswa sebagai penguat agar siswa lebih memahami materi yang sedang dipelajari. Nantinya tugas yang sudah diberikan oleh guru akan dikerjakan oleh siswa secara mandiri dan guru memberikan batas waktu tertentu bagi siswa untuk mengumpulkan hasil pekerjaannya. Lalu tugas yang diberikan oleh guru akan dikirimkan langsung kepada guru melalui fitur chat, Seperti yang ada pada gambar 4. Setelah sampai pada akhir pembelajaran, guru akan memberikan refleksi mengenai proses pembelajaran hari itu dengan menggunakan fitur pesan suara yang ada di aplikasi whatsapp.

Tabel 2. Kekurangan dan Kelebihan Pembelajaran Daring Berbasis Whatsapp

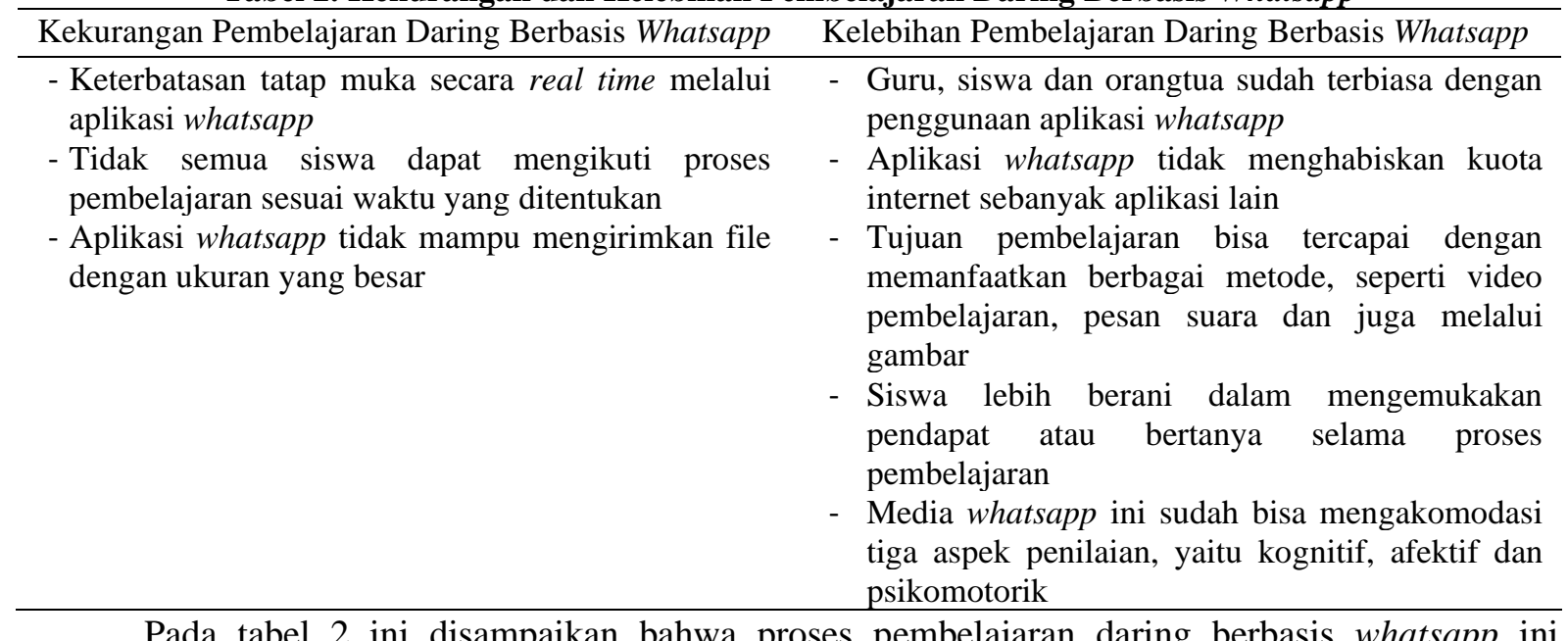
memiliki kekurangan dan kelebihan dalam proses pelaksanaannya. Kekurangan yang pada penerapan ini kebanyakan berisi tentang masalah terhadap waktu, yaitu tentang adanya beberapa siswa yang tidak bisa secara tepat waktu mengikuti pembelajaran, baik ketika melaksanakan pembukaan atau ketika pengumpulan tugas. Selain itu aplikasi whatsapp ini memiliki keterbatasan dalam melakukan video call, sehingga tidak bisa mengakomondasi tatap muka secara real time melalui fitur video call bagi semua siswa. Namun dari adanya beberapa kekurangan dalam proses pembelajaran daring berbasis whatsapp ini, faktor-faktor utama dari proses pembelajaran sendiri masih bisa dicapai dan dijalankan dengan baik.

\section{Diskusi}

Tujuan pembelajaran yang telah ditentukan bisa terlaksana dan dicapai serta aspek-aspek penilaian baik aspek kognitif bisa dijalankan melalui fitur grup chat yang dapat mengirimkan link soal dari aplikasi google form, aspek afektif dan psikomotorik juga dapat dinilai melalui fitur sharing video dan juga video call. Hal ini senada dengan yang disampaikan penelitian (Mirzon Daheri, Juliana, Deriwanto, 2020) bahwa penerapan aplikasi whatsapp dalam proses pembelajaran dapat menghasilkan dampak yang positif bagi pelaksanaan proses pembelajaran. 


\section{Simpulan}

Penelitian ini mendapatkan sebuah kesimpulan yang dapat diambil diantaranya, pertama pembelajaran daring yang dilaksanakan di SD Yapita Surabaya dapat dilaksanakan dengan baik menggunakan aplikasi whatsapp. Kedua, kelebihan yang didapat dari penggunaan aplikasi whatsapp ialah aplikasi ini mampu mengakomodasi proses pembelajaran dengan baik melalui fitur-fitur yang dapat menunjang keberhasilan pelaksanaan pembelajaran secara daring. Untuk kekurangan dari penggunaan aplikasi whatsapp ialah masih memiliki keterbatasan untuk melakukan tatap muka secara real time melalui fitur yang dimiliki. Serta belum mampu memberikan batasan waktu agar siswa tidak mengumpulkan atau mengerjakan tugas melebihi waktu yang ditentukan.

\section{Daftar Pustaka}

Abidah, A., Hidaayatullaah, H. N., Simamora, R. M., Fehabutar, R. M., Mutakinati. L. (2020). The Impact of Covid-19 to Indonesian Education and Its Relation to the Philosophy of "Merdeka Belajar". Studies in Philosophy of Science and Education (SiPoSE). 1(1), 38-49. https://doi.org/10.46627/sipose.v1i1.9

Afandi, M., Chamalah, E., Wardani, O., P. (2013). Model dan Metode Pembelajaran di Sekolah. Semarang: Unissula Press.

Amal, B. K. (2019). Pembelajaran Blended Learning Melalui Whatsapp Group (WAG). Paper dipresentasikan di Seminar Nasional Fakultas Ilmu Sosial, Universitas Negeri Medan, Medan, 700-702.

Daheri, M., Juliana, Deriwanto, Amda, D.A. (2020). Efektifitas Whatsapp Sebagai Media Belajar Daring. Jurnal Basicedu. 4(4), 775-783. https://doi.org/10.31004/basicedu.v4i4.445

Dewi, W. A. F. (2020). Dampak Covid-19 Terhadap Implementasi Pembelajaran Daring Di Sekolah Dasar. Jurnal Ilmu Pendidikan. 2(1), 55-61. https://doi.org/10.31004/edukatif.v2i1.89

Hakim, M., Mulyapradana, A. (2020). Pengaruh Penggunaan Media Daring dan Motivasi Belajar Terhadap Kepuasan Mahasiswa Pada Saat Pandemi Covid-19. Jurnal Sekretari dan Manajemen. 4(2), 154-160. https://doi.org/10.31294/widyacipta.v4i2.8853

Hamalik, O. (2011). Kurikulum dan Pembelajaran. Jakarta: Bumi Aksara.

Handarini, O. I., Wulandari, S. S. (2020). Pembelajaran Daring Sebagai Upaya Study From Home (SFH) Selama Pandemi Covid 19. Jurnal Pendidikan Administrasi Perkantoran. 8(3), 496503. https://journal.unesa.ac.id/index.php/jpap/article/view/8503

Khusniyah, N. L., Hakim, L. (2019). Efektifitas Pembelajaran Berbasis Daring: Sebuah Bukti Pada Pembelajaran Bahasa Inggris. Jurnal Pemikiran dan Penelitian Pendidikan. 17(1), 19-33. 10.20414/jtq.v17i1.667

Nurdyansah. Fahyuni, E., F. (2016). Inovasi Model Pembelajaran Sesuai Kurikulum 2013. Sidoarjo: Nizamia Learning Center.

Nurhayati, I., Lestari, P. (2020). Pembelajaran Berbasis Whatsapp dan Flash Game Player. Jurnal $\begin{array}{llll}\text { Ilmiah } & \text { Pendidikan } & \text { Matematika. }\end{array}$ https://ejournal.stkipbbm.ac.id/index.php/mtk/article/view/485

Prajana, A. (2017). Pemanfaatan Aplikasi Whatsapp Dalam Media Pembelajaran Di Uin Ar-Raniry Banda Aceh. Jurnal Pendidikan Teknologi Informasi. 1(2), 122-133. http://dx.doi.org/10.22373/cs.v1i2.1980 
ZAHRA: Research And Tought Elmentary School Of Islam Journal Vol. (2) (1), (Maret)(2021), (Halaman)(13-23)| 23

Pratama, H., Yusro, A. C. (2016). Implementasi Whatsapp Mobile Learning Untuk Meningkatkan Hasil Belajar Mahasiswa Pokok Bahasan Pengenalan Komponen Elektronika. Jurnal Pendidikan Fisika dan Keilmuan. 2(2), 65-69. http://doi.org/10.25273/jpfk.v2i2.696

Putria, H., Maula, L. H., Uswatun, D. A. (2020). Analisis Proses Pembelajaran Dalam Jaringan (DARING) Masa Pandemi COVID-19 Pada Guru Sekolah Dasar. Jurnal Basicedu. 4(4), 861872. https://doi.org/10.31004/basicedu.v4i4.460

Rigianti, H. A. (2020). Kendala Pembelajaran Daring Guru Sekolah Dasar Di Kabupaten Banjarnegara. Jurnal Pendidikan dan Pembelajaran Ke-SD-an. 7(2), 297-302. https://doi.org/10/31316/esjurnal.v7i2.768

Sadikin, A., Hamidah, A., ( 2020). Pembelajaran Daring di Tengah Wabah Covid-19. Jurnal Ilmiah Pendidikan Biologi. 6(2), 214-224. https://doi.org/10.22437/bio.v6i2.9759

Sahidillah, M. N., Miftahurrisqi, P. (2019). Whatsapp Sebagai Media Literasi Digital Siswa. Jurnal Varia Pendidikan. 31(1), 52-57. 10.23917/varidika.v1i1.8904

Sofyana, L., Rozaq, A. (2019). Pembelajaran Daring Kombinasi Berbasis Whatsapp Pada Kelas Karyawan Prodi Teknik Informatika Universitas PGRI Madiun. Jurnal Nasional Pendidikan Informatika. 8(1), 81-86. 10.23887/janapati.v8i1.17204

Sugiyono. (2013). Metode penelitian pendidikan pendekatan kuantitatif, kualitatif, dan R\&D. Bandung: Alfabeta.

Utomo, S. W., Ubaidillah, M. (2018). Pemanfaatan Aplikasi Whatsapp Pada Pembelajaran Berbasis Masalah Untuk Mata Kuliah Akuntansi Internasional Di Universitas PGRI Madiun. Jurnal Teknologi Pendidikan. 6(2), 199-211. https://doi.org/10.31800/jtp.kw.v6n2.p199--211 